\title{
Planetaarinen kriisi tekee vastuullisuusasiantuntijoista aikuiskouluttajia
}

\author{
wy \\ Kun yhteiskunta siirtyy vähähiilisempään \\ tulevaisuuteen, vastuullisuudesta tulee osa useaa \\ työnkuvaa. Muutokset päästöjen vähentämiseksi \\ yhteiskunnassa vaativat toimia kaikilla aloilla. \\ Muutokset ovat niin laajoja, että jokaisen on otettava \\ vastuullisuusasiat huomioon työssään.
}

\begin{abstract}
KESTÄVÄN KEHITYKSEN tutkimuksen mukaan useiden läntisten maiden tulee vähentää kasvihuonekaasupäästöjään 80-98 prosentilla nykytasosta vuoteen 2050 mennessä (Committee on Climate change 2019; Työ- ja elinkeinoministeriö 2014; Wiehe ym. 2020), jotta maapallon keskilämpötila ei nouse yli kahta astetta. Vain näin voidaan estää planeettamme elinolojen muuttuminen kohtalokkaiksi maanpäälliselle elämälle. Globaaliin ilmastokriisin luomaan haasteeseen vastataan muun muassa pitkän aikavälin ilmastotavoitteilla, jotka toimivat strategisen tason ohjeina. Tavoitteiden saavuttamiseen osallistuvat kaikki yhteiskunnan toimijat: julkinen ja yksityinen sektori sekä kansalaisyhteiskunta ja kuluttajat. Suomi on sitoutunut hiilineutraaliuteen vuoteen 2035 mennessä. Mitä se tarkoittaa käytännössä?
\end{abstract}

Vastuullisuusalan ammattilaiset työskentelevät muun muassa julkisen ja yksityisen sektorin organisaatioissa ympäristövastuun ja kestävän kehityksen tehtävissä. Vastuullisuuskäsite mukautuu usein toimialan mukaan, mutta esimerkiksi 'yritysvastuulla' tarkoitetaan yleensä vapaaehtoisia toimia, joilla yritys toteuttaa yhteiskuntavastuutaan sidosryhmien odotusten mukaisesti (Harmaala \& Jallinoja 2012). Vastuullisuusala tarkoittaa siten suunnittelua, kehittämistä ja viestimistä organisaation vastuullisesta toiminnasta. Kestävä kehitys ja yritysvastuu ohjaavat organisaatioita kehityssuuntaan, jossa liiketoiminnassa pyritään taloudellisten argumenttien lisäksi ottamaan huomioon ympäristövaikutukset ja sosiaaliset vaikutukset.

Vastuullisuusalan ammattilaisten tehtäviin kuuluu usein organisaation toiminnasta, tuotteista ja 


\section{KAIKISTA AMMATTILAISISTA}

\section{EI TULE VASTUULLISUUS-}

AMMATTILAISIA.

palveluiden tuottamisesta johtuvien sosiaalisten ja ympäristövaikutusten pienentäminen. Esimerkiksi sosiaalisen vastuun näkökulmasta yritys voi pyrkiä ostamaan tuotteita alihankkijoilta, jotka jatkuvasti kehittävät ja valvovat tuotteidensa valmistusoloja lähtömaassa. Esimerkkejä ympäristövastuusta ovat päästöjen vähentäminen, energiatehokkuustoimenpiteet ja YK:n kestävän kehityksen tavoitteiden huomioon ottaminen. Vastuullisuustyötä tehdään organisaatiotasolla. Se rakentuu osaksi eri toimialojen päästöjen vähennystä ja sitä kautta edelleen osaksi Suomen yhteiskunnan matkaa hiilineutraaliuteen. Monialaisen ja laajan työnkuvan lisäksi vastuullisuusalan ammattilaiset pyrkivät tuomaan esiin vastuullisuusteemoja työyhteisössään. Yksi jatkuva työtehtävä on aikuisten ympäristötietoisuuden lisääminen.

Tällaiset työtehtävät vaativat viestintä- ja neuvottelutaitoja, joita ei valitettavasti opeteta riittävästi vastuullisuusalan yliopistokoulutuksessa. Siksi opetusta pitäisi päivittää työelämän haasteita vastaavaksi. Lisäksi olisi suositeltavaa lisätä työelämässä oleville muiden alojen ammattilaisille polkuja vastuullisuusteemoja koskevan osaamisen kehittämiseen. Onkin tärkeää tunnistaa aikuiskoulutuksen tarpeet ja vastaanottajat työelämässä ja suunnitella heille sopivia koulutusmahdollisuuksia.

\section{KESTÄVÄN KEHITYKSEN LÄPIMURTO TYÖPAIKOILLA}

Pohjoismaiden yritysvastuuverkosto FIBS toteutti vuonna 2019 ensimmäisen laajan yritysvastuuammattilaisuutta koskevan kyselytutkimuksen jäsenilleen, Suomessa toimiville kestävän kehityksen asiantuntijoille. Sen mukaan sisäinen viestintä ja koulutus ovat merkittäviä ja aikaa vieviä tehtäviä (FIBS 2020a). Näillä tehtävillä viitataan työelämässä olevien koulutukseen eli ympäristötietoisuuden lisäämiseen. Ylimääräiset ympäristökasvatuksen tehtävät saattavat kuormittaa asiantuntijoita. Jotta vastuullisuusalan tehtäviä voidaan viedä eteenpäin organisaatiossa, on saatava hyväksyntä päätöksentekijöiltä. Ympäristökasvatus alkaakin usein johtoportaasta, minkä jälkeen voidaan siirtyä muille organisaatiotasoille.

Työelämässä olevien ympäristökasvatus voi tarkoittaa sen selostamista, miten ilmastonmuutos etenee, tai yksityiskohtaisen katsauksen luomista tietyn tuotteen valmistuksesta syntyviin ympäristövaikutuksiin. Vastuullisuusteemoista tuleekin kertoa yleistajuisesti ja vaihtuvan kuulijakunnan tarpeiden pohjalta. Kun työntekijät ymmärtävät perusasiat, on helpompi perustella esimerkiksi organisaation huomion kiinnittämistä henkilöstön liikkumistapoihin. Sekin käy ymmärrettäväksi, mihin sisäisiin toimintoihin ja osastoihin käsiteltävä aihe on sidoksissa. Muutokset henkilöstön liikkumistavoissa vähentävät organisaation ympäristökuormitusta tai hiilijalanjälkeä, parantavat paikallista ilmanlaatua ja jopa lisäävät työntekijöiden hyvinvointia, mikäli he kulkevat työmatkan lihasvoimin. Työpaikalla tapahtuvan koulutuksen ja tiedotuksen vaikutukset laajenevat organisaation ulkopuolelle, kun työntekijät tekevät vapaa-ajallaan ostopäätöksiä kuluttajina.

FIBSin kyselytutkimuksessa nousivat esille vastuullisuusalan ammattilaisten työssään kokema muutosvastarinta ja ennakkoluulot. Monialaisen ja laajan substanssiosaamisen lisäksi vastuullisuustyötä täytyy pystyä perustelemaan ja oikeuttamaan jatkuvasti, ja pahimmillaan on kyettävä sietämään kyseenalaistamista ja vähättelyä. (FIBS 2020a.)

FIBSin ympäristövastuun koordinaattori Angelina Kuokkanen kommentoi kyselytutkimuksen esiin nostamia vastuullisuustyön kääntöpuolia: ”Tämän hetken yritysvastuun ammattilaiset ovatkin uraauurtavia muutoksen tekijöitä, jotka joutuvat laaja-alaisen työnsä ohessa tekemään myös paljon sisäistä pr-työtä vastuullisuuden läpi lyömiseksi.” Argumentointi-, neuvottelu- ja vaikuttamistaidot ovat tärkeitä kestävän kehityksen asiantuntijoille. Kyselytutkimuksen tuloksista kuvastuu suhteellisen uusi ammattiala, joka etsii paikkaansa suomalaisten organisaatioiden arvohierarkiassa. (FIBS 2020b.) Viestinnän ja vuorovaikutustaitojen tarpeellisuus korostuvat. 


\section{VASTUULLISUUS INTEGROITUU USEAAN} TYÖTEHTÄVÄÄN

Usein kestävään kehitykseen liittyvät toiminnot ovat erillisiä organisaation muista toiminnoista. Kun yhteiskunta siirtyy vähähiilisempään tulevaisuuteen, vastuullisuudesta tulee osa useaa työnkuvaa. Oman työkokemuksemme pohjalta organisaatioiden johdon, henkilöstöosaston, myynnin, tuotteiden ja palveluiden kehityksen, osto- ja laatuosaston, markkinoinnin ja viestinnän ammattilaisten työtehtävät sisältävät suoraan tai välillisesti vastuullisuusteemojen käsittelyä. Tällä tavoin vastuullisuus integroituu osastojen arkeen. Kaikista ammattilaisista ei kuitenkaan tule vastuullisuusammattilaisia, vaan tarvittavat muutokset päästöjen vähentämiseksi yhteiskunnassamme vaativat kaikilla aloilla toimia, jotka eivät saisi jäädä erillisiksi muusta toiminnasta. Muuten ilmastotekojen vaikutukset saattavat jäädä pinnallisiksi, eikä henkilöstö välttämättä edes tiedä niistä. Tämä on aikuiskasvatuksen paikka: meidän täytyisi tukea ihmisiä vielä enemmän kestävän tulevaisuuden rakentajina ja vaikuttajina. (Laakkonen \& Kosonen 2018.)

Yleisesti on ajateltu, että aiemman koulutuksen kautta hankitut valmiudet kantavat läpi työuran. Oletuksen mukaan työntekijöiden osaaminen vahvistuu ja uudistuu osana työkokemusta, ja he hakevat itsenäisesti päivitystä osaamiseen, mikäli kokevat sen tarpeelliseksi. (Lehtinen, 2012). Itsestään selvänä pidetään sitä, että työntekijöillä on voimavaroja etsiä puuttuvia palasia osaamiseensa itsenäisesti oman työnsä ohessa. Kasvatustieteen professori Erno Lehtinen (2012) on tutkinut korkeasti koulutettujen osaamisen päivittämistä. Hän huomauttaa, että asiantuntijuustutkimuksen löydökset osoittavat oletuksen vääräksi. Muutosten hallitseminen ja vaadittavan asiantuntijuuden uudistaminen itsenäisesti päivätyön rinnalla on liian vaativaa yksittäiselle työntekijälle (Ericsson ym. 2006; Lehtinen 2012).

Vastuullisuusteemojen yhteydessä haetaan ymmärrystä ympäristökysymysten perusteista ja siitä, miten ne voidaan ottaa huomioon omassa työssä: miten esimerkiksi henkilöstöosasto nostaa esille vastuullisuusasiat työhaastatteluissa, mikäli ne muo- dostuvat osaksi organisaation arvoja. Aiheet ovat monialaisia ja laajoja ja saattavat tuntua abstrakteilta ja kaukaisilta, eivätkä työntekijät aina osaa sanoittaa puuttuvaa osaamista riittävän yksityiskohtaisesti.

\section{VIESTINTÄ- JA NEUVOTTELUTAIDOT KUULUVAT VASTUULLISUUSALAN ASIANTUNTIJAN KOULUTUKSEEN}

Suomen yliopistojen rehtorineuvoston (UNIFI) mukaan yliopistot ovat keskeisiä toimijoita ilmastokriisin torjunnassa ja ratkaisussa. Erityisen tärkeitä ne ovat tarvittavan asiantuntemuksen luomisessa ja turvallisen, vakaan yhteiskunnan vaalimisessa. Yliopistot tuottavat uutta tietoa ja kouluttavat tulevaisuuden osaajia ja tiedostavia kansalaisia (UNIFI 2020). Marraskuussa 2020 UNIFI julkaisi yliopistojen yhteiset kestävän kehityksen ja vastuullisuuden teesit. 12 teesin tavoite on korostaa kestävää kehitystä korkeakoulujen tutkimuksessa ja opiskelijoiden kasvatuksessa sekä edistää konkreettisia muutoksia. Neljäs teesi tähdentää, että akateemisten asiantuntijataitojen opetuksessa pitäisi huomioida vastuullisuuden valmiudet, kuten kriittinen ja eettinen ajattelu, yhteistyö- ja vuorovaikutustaidot, muutosjohtaminen ja oman asiantuntijuuden tunnistaminen. Kestävää kehitystä ja yritysvastuuta opetetaan useassa suomalaisessa yliopistossa maisteritasolla.

Nykyisellään vastuullisuusalan korkeakoulutus ei välttämättä valmista opiskelijoita työelämän realiteetteihin (MacDonald ym. 2016). Vastuullisuusalan aiheet, kuten ilmastonmuutoksen hillintä tai luonnon monimuotoisuuden muutokset, ovat moniulotteisia ja toisinaan vaikeita ymmärtää (Brundiers \& Wiek 2017). Kestävän kehityksen koulutus keskittyykin usein oppiaineen sisältöosaamiseen, esimerkiksi ympäristön hallintajärjestelmiin, kestävään kehitykseen prosessina, YK:n kestävän kehityksen tavoitteisiin, innovaatioihin, energian- ja vedenkulutukseen, kierrättämiseen ja jätehuoltoon. Jotta opittua voidaan hyödyntää työelämässä, täytyy lisäksi hallita yleiset työelämätaidot (Wiek ym. 2011). Tutkimusten mukaan vastuullisuusalan koulutus kuitenkin harvoin sisältää tehokkaan ja myötätuntoisen viestinnän opetusta (Allen ym. 2014; MacDonald ym. 2016; 


\section{VIESTINT $\ddot{A}-$ JA}

\section{VUOROVAIKUTUSTAIDOT}

OVAT TÄRKË̈ OSA

\section{VASTUULLISUUSALAN}

AMMATTILAISEN TYÖT ̈̈.

Willard ym. 2010). Liian harvoin maisteriohjelmien opintojaksoihin on integroitu viestintä-, väittely- tai neuvottelusisältöjä. Sen sijaan opiskelijoiden odotetaan oppivan viestintä- ja vuorovaikutustaitoja muissa opinnoissa ja työelämässä.

Yliopistokoulutuksessa viestintätaitoja voi harjoitella vain harvoilla kursseilla, kuten projektityön kursseilla, jotka toteutetaan yhdessä yritysten kanssa (Jääskelä ym. 2018; Ainiala ym. 2020). Todellisuudessa opiskelijat tapaavat yritysten edustajien kanssa vain muutaman kerran. Lisäksi opintojakson aikataulu on usein tiukka ja lopputulokset esitellään luennoilla, joilla vain harvoin on mahdollisuutta syvälliseen keskusteluun ja perusteellisen palautteen antamiseen. Aika ajoin tämä epäkohta nousee esille opiskelijoiden kurssipalautteissa, ja opiskelijat toivovatkin enemmän vuorovaikutusta yritysten edustajien kanssa ymmärtääkseen, olivatko heidän töidensä tulokset vakuuttavia ja siten merkityksellisiä.

Viestintä- ja vuorovaikutustaidot, kuten neuvottelu ja eri osapuolten vakuuttaminen, ovat tärkeä osa vastuullisuusalan ammattilaisen työtä. Opintojen aikana opiskelijoiden on helppo jäädä "omaan kuplaan”, jossa kaikille on selvää huomioida vastuullisuus liiketoiminnassa. Työelämässä he kuitenkin huomaavat, että talous hallitsee keskustelua, ja juuri silloin viestintä- ja neuvottelutaidot ovat tärkeitä. Vastuullisuusalan ammattilaisten työ sisältää nykyisten toimintatapojen ja ajatusmallien kriittistä arviointia ja niiden jatkuvaa uudistamista. Usein joudutaankin nousemaan vallitsevaa tilaa ja toimintatapaa, status quota, vastaan, sillä muutokset eivät miellytä kaikkia.

Tutkimus osoittaa, että vastavalmistuneet, jotka suorittivat tutkintonsa suomalaisessa yliopistossa eivät muodostaneet riittävää kompetenssia viestintä- ja yhteistyötaidoista. (Tuononen ym. 2019.) Oppimista voitaisiin tukea myös maisteriopinnoissa tarjoamalla lisää mahdollisuuksia taitojen harjoitteluun turvallisessa ja ystävällisessä ilmapiirissä. Suomalaisessa opetuskulttuurissa harva opiskelija uskaltaa haastaa opettajaa luennoilla pohdiskelevilla kysymyksillä, vaikka kestävän kehityksen alalle onkin ominaista tasapainottelu eri tahojen intressien kanssa.

Yksi vaihtoehto on lisätä pakollisia viestintä-, väittely- tai neuvottelukursseja maisteriohjelmiin. $\mathrm{Ne}$ vain ovat yhä joustamattomampia kokonaisuuksia, ja opiskelijoilla on aiempaa vähemmän valinnaisia opintoja. Toinen vaihtoehto on integroida väittelyä omana opetusmenetelmänään opintojaksoihin. Muiden hyvien opetusmenetelmien, kuten ryhmätöiden, lisäksi yhden luennon voisi korvata väittelytunnilla, jolle opiskelijat valmistelevat omia argumenttejaan käsiteltävästä aiheesta. He voisivat esimerkiksi miettiä argumentteja uusiutuvaan energiaan siirtymisen puolesta tai vastaan, mikä syventäisi heidän ymmärrystään siitä, miksi uusiutuvaa energiaa vastustetaan yhteiskunnassamme ja miten eri tahojen kanssa voisi käydä dialogia. Väittely- ja neuvottelutaitojen kehittämiseen sopisivat lisäksi virtuaalityökalut, esimerkiksi pelit ja simulaatiot sidosryhmävuorovaikutustilanteista. Maisteriohjelmien opetussuunnitelmien kuvauksiin ja oppimistavoitteisiin pitäisikin sisällyttää olennaiset viestintä- ja vuorovaikutustaidot. Se valmentaisi kestävän kehityksen opiskelijoita nykyistä paremmin työelämän haasteisiin.

\section{VASTUULLISUUSOPINNOT AVOIMESSA YLIOPISTOSSA ANTAVAT TUKEA TYÖHÖN}

Vastuullisuusalan ammattilaisten työtehtäviin kuuluu usein jatkuva ympäristötietoisuuden lisääminen. Aikuisten kestävän kehityksen kasvatus ei voi kuitenkaan olla vain asiantuntijoiden harteilla, joten on tärkeää pohtia, miten työelämässä olevien osaamista voidaan päivittää. Vastuullisuusteemat läpäisevät yhä useammin kaiken tekemisen organisaatioissa. Emme silti voi olettaa, että työntekijät oman työnsä ohessa päivittävät aktiivisesti vastuullisuusosaamistaan, vaan on tärkeää tunnistaa aikuiskoulutuksen tarpeet ja vastaanottajat työelämässä. 
Avoimen yliopiston kestävän kehityksen opinnot ovat hyvä ja luotettava keino päivittää työelämässä olevien osaamista ja tietoisuutta. Suomen UNIFIn kestävän kehityksen teeseissä todetaan, että "jatkuvan oppimisen periaatteen mukaisesti yliopistot kehittävät ja tarjoavat kestävyyskoulutusta yhdenvertaisuuden ja aktiivisen kansalaisuuden tukemiseksi" (teesi 4, UNIFI 2020). Opetustarjonnan, kuten tarvelähtöisten opintojaksojen, suunnittelussa on tärkeää huomioida aikuisopiskelijoiden ja organisaatioiden näkökulmia ja kokemuksia. Avoimen yliopiston kestävyystyön resursointi on keskeinen keino luoda lisää kohtaamispaikkoja, joissa tuetaan työelämässä olevien vastuullisuusosaamista.

Kestävää kehitystä on mahdollista opiskella usean palveluntarjoajan kautta. Avoimen yliopiston tarjontaa tulisi lisätä, ja kotimaisia opintokokonaisuuksia kohdentaa ja räätälöidä esimerkiksi toimialoittain tai työtehtävittäin. Näin osallistujan olisi vaivatonta löytää oikea, kulloisia tarpeita vastaava kokonaisuus. Erikoistumisen mahdollisuus motivoisi työntekijöitä päivittämään osaamistaan ja vaikuttaa uudistumiskykyyn ja oman alan osaamisen tason parantamiseen. Yliopistojen ja yritysten välistä dialogia lisäämällä on mahdollista parantaa avoimen yliopiston opintotarjontaa vastaamaan yhä paremmin työssä olevien tarpeita.

\section{POHDINTA}

Vastuullisuusalan ammattilaiset toimivat usein organisaatioiden muutosagentteina, ja heillä on keskeinen tehtävä työelämässä olevien aikuisten ympäristökasvatuksessa. Kun vastavalmistunut vastuullisuusalan ammattilainen siirtyy opinnoista työelämään, hänelle saattaa tulla yllätyksenä työntekijöiden ympäristötietoisuuden jatkuva lisääminen. Yllätyksenä saattaa tulla myös se, miten talouden kysymykset hallitsevat päätöksentekoa. Jotta vastuullisuusteemat saavat jalansijaa organisaatiossa, alan ammattilaiselta vaaditaan neuvottelu- ja väittelytaitoja. Kestävän kehityksen korkeakouluopetusta tulisikin päivittää viestintä- ja vuorovaikutustaidoilla, jotta vastavalmistuneet voisivat nykyistä paremmin viedä kestävyysagendaa eteenpäin.

UNIFIn mukaan yliopistot ovat keskeisiä toimijoita ilmastokriisin torjunnassa ja ratkaisussa korkeakoulutuksella ja tutkimuksella. Työelämässä olevat eri alojen ammattilaiset taas tarvitsevat erilaisia polkuja vastuullisuusteemoihin liittyvän osaamisensa kehittämiseen. Avoin yliopisto voi toimia yhtenä tärkeänä kouluttajana ympäristövastuuta ja sosiaalista vastuuta koskevassa osaamisessa.

Vastuullisuus liittyy yhä enemmän kaikkeen toimintaan alaan katsomatta. Näin kaikki yhteiskuntamme toimijat siirtyvät asteittain ja radikaalein muutoksin nykyistä vähähiilisempään tulevaisuuteen. Olisikin tärkeää suunnitella aikuiskoulutuksen kursseja yhdessä eri toimijoiden kanssa, jotta ne palvelisivat hyvin yhteiskuntamme tarpeita.

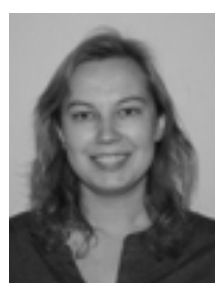

\section{MINNA KÄYRÄ}

KTM, väitöskirjatutkija Jyväskylän yliopiston kauppakorkeakoulu

(iD) https://orcid.org/0000-00019718-1706.

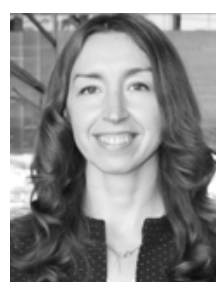

ANGELINA KORSUNOVA

$\mathrm{KTT}$, tohtoritutkija Kestävyystieteen instituutti maatalous- ja metsätieteellinen tiedekunta Helsingin yliopisto

(D) https://orcid.org/0000-00018424-2426. 


\section{LÄHTEET}

Ainiala, T., Olsson, P., Mattila, H., Vesalainen, M. (2020). Työelämätaidot korkeakouluopetuksessa: Opiskelijoiden kokemuksia asiantuntijuuden ja taitojen kehittymisestä monialaisella kaupunkitutkimuksen projektikurssilla. Aikuiskasvatus, 40(2), 96-111. https://doi. org/10.33336/aik.95449

Allen, J. H., Beaudoin, F., Lloyd-pool, E., Sherman, J. (2014). Pathways to Sustainability

Careers: Building Capacity to Solve Complex Problems. Sustainability, 7(1), 7-53.

Committee on climate change (2019). Net Zero: The UK's contribution to stopping global warming. [online]. https://www.theccc.org.uk/wp-content/ uploads/2019/05/Net-Zero-The-UKs-contribution-tostopping-global-warming.pdf.

Ericsson, K. A., Charness, P. J., Feltovich, P. J. \& Hoffmann, R. R. (2006). The

Cambridge Handbook of Expertise and Expert Performance. Cambridge: Cambridge University Press.

FIBS (2020a). Muutoksentekijät. Yritysvastuuammattilaiset Suomessa -tutkimusraportti. Helsinki: FIBS ry.

FIBS (2020b). FIBS-tutkimus: Yritysvastuu on kutsumusammatti - työn suurimpia haasteita ovat monialaisuus, muutosvastarinta ja liian vähäiset resurssit. [online]. https://www.fibsry.fi/ajankohtaista/ tutkimus-yritysvastuu-on-kutsumusammattityon-suurimpia-haasteita-ovat-monialaisuusmuutosvastarinta-ja-liian-vahaiset-resurssit

Harmaala, M.-M. \& Jallinoja, N. (2012). Yritysvastuu ja menestyvä liiketoiminta. Helsinki: SanomaPro.

Jääskelä, P., Nykänen, S. \& Tynjälä, P. (2018). Models for the development of generic skills in Finnish higher education. Journal of Further and Higher Education, 42(1), 130-142.
Laakkonen, E. \& Kosonen, T. (2018). Kuinka tukea aikuisia kestävän tulevaisuuden rakentajina? Aikuiskasvatus, 38(4), 348-349. https://doi. org/10.33336/aik.88386

Lehtinen, E. (2012). Korkeakoulutuksen rakenteiden pitäisi tukea aikuiskoulutusta. Aikuiskasvatus, 32(4), 298-302. https://doi.org/10.33336/aik.94008

MacDonald, L. \& Shriberg, M. (2016). Sustainability leadership programs in higher education: Alumni outcomes and impacts. Journal of Environmental Studies and Sciences, 6(2), 360-370.

Tuononen, T., Parpala, A. \& Lindblom-Ylänne, S. (2019) Graduates' evaluations of usefulness of university education, and early career success - a longitudinal study of the transition to working life. Assessment \& Evaluation in Higher Education, 44(4), 581-595, DOI: 10.1080/02602938.2018.1524000

Työ- ja elinkeinoministeriö (2014). Energia- ja ilmastotiekartta 2050. Työ- ja elinkeinoministeriön julkaisuja. Energia ja ilmasto 31/2014. https://tem. fi/documents/1410877/2628105/Energia+ja+ilmas totiekartta+2050.pdf/1584025f-c5c7-456c-a912aba0ee3e5052 (22.10.2020).

UNIFI (2020). Kestävän kehityksen ja vastuullisuuden teesit. https://www.unifi.fi/viestit/kestavankehityksen-ja-vastuullisuuden-teesit (luettu 22.10.2020).

Wiek, A., Withycombe, L., Redman, C. \& Mills, S. (2011). Moving Forward on Competence in Sustainability Research and Problem Solving. Environment: Science and Policy for Sustainable Development, 53(2), 3-13.

Willard, M., Wiedmeyer, C., Flint, W., R., Weedon, J., S., Woodward, R., Feldman, I. \& Edwards, M. (2010). The sustainability professional: 2010 Competency survey report. Environmental Quality Management, 20(1), 49-83. 